University of Nebraska - Lincoln

DigitalCommons@University of Nebraska - Lincoln

1989

\title{
GRAZING SELECTIVITY AND IN VIVO DIGESTIBILITY OF SWITCHGRASS STRAINS SELECTED FOR DIFFERING DIGESTIBILITY
}

\author{
M. G. Ward \\ J. K. Ward \\ Bruce E. Anderson \\ University of Nebraska-Lincoln, banderson1@unl.edu \\ Kenneth P. Vogel \\ University of Nebraska-Lincoln, kvogel1@unl.edu
}

Follow this and additional works at: https://digitalcommons.unl.edu/usdaarsfacpub

Ward, M. G.; Ward, J. K.; Anderson, Bruce E.; and Vogel, Kenneth P., "GRAZING SELECTIVITY AND IN VIVO DIGESTIBILITY OF SWITCHGRASS STRAINS SELECTED FOR DIFFERING DIGESTIBILITY" (1989).

Publications from USDA-ARS / UNL Faculty. 1883.

https://digitalcommons.unl.edu/usdaarsfacpub/1883

This Article is brought to you for free and open access by the U.S. Department of Agriculture: Agricultural Research Service, Lincoln, Nebraska at DigitalCommons@University of Nebraska - Lincoln. It has been accepted for inclusion in Publications from USDA-ARS / UNL Faculty by an authorized administrator of DigitalCommons@University of Nebraska - Lincoln. 


\title{
GRAZING SELECTIVITY AND IN VIVO DIGESTIBILITY OF SWITCHGRASS STRAINS SELECTED FOR DIFFERING DIGESTIBILITY1
}

\author{
M. G. Ward ${ }^{2}$, J. K. Ward ${ }^{3}$, \\ B. E. Anderson ${ }^{4}$ and K. P. Vogel ${ }^{5}$ \\ University of Nebraska, Lincoln 68583-0909
}

\begin{abstract}
Animal selectivity and digestibility differences among switchgrass strains selected for different in vitro dry matter digestibilities (IVDMD) were measured in a grazing trial with esophageally fistulated steers and a sheep digestion trial. Extrusa selected by esophageally fistulated steers grazing high-IVDMD (Trailblazer), Pathfinder and low-IVDMD strains of switchgrass were compared, as were top and whole plant hand-clipped samples from each strain. Trailblazer extrusa had higher $(P<.1)$ in vitro organic matter disappearance (IVOMD) and lower $(P<.1)$ NDF and ADF than Pathfinder extrusa. Extrusa from all three strains appeared to be of higher quality than top or whole plant hand-clipped samples. In vitro organic matter disappearance tended to be highest for Trailblazer top hand-clipped samples. Composition of hand-clipped samples among strains was not significantly different. Mature crossbred wethers were used to compare Trailblazer and Pathfinder switchgrass hay in a digestion trial. No differences $(P>.1)$ were detected between strains for DMI or apparent digestibility of DM, NDF, ADF and CP. Extrusa from Trailblazer switchgrass that had been selected for whole plant IVDMD had higher IVOMD; however, there was no indication that steers selected a differentially higher IVOMD for one strain than another.
\end{abstract}

(Key Words: Panicum virgatum, Selectivity, Digestibility, Esophageal Fistula, Steers, Lambs.)

J. Anim. Sci. 1989. 67:1418-1424

\section{Introduction}

Warm-season $\left(C_{4}\right)$ grasses generally are lower in forage quality than temperate- or cool-season grasses (Moore and Mott, 1973; Wilson et al., 1983). Plant geneticists and breeders have made significant improvements in $\mathrm{C}_{4}$ selections for forage quality over the last 20 yr (Utley et al., 1974; Burton and Monson, 1981). Modest improvements in digestibility of $\mathrm{C}_{4}$ forages can increase animal performance greatly (Burton, 1974; Monson et al., 1977).

${ }^{1}$ Published with the approval of the Director as Paper No. 8697 Journal, Ser., Nebraska Agric. Exp. Sta. 69101.

2Present address: Moorman Mfg. Co., North Platte, NE

${ }^{3}$ Dept. of Anim. Sci.

'Dept. of Agron.

SUSDA-ARS.

Received August 5, 1988.

Accepted November 23, 1988.
Coastcross-1 bermudagrass (Cynodon dactylon; Coastal $\times$ Kenya $45 \# 14$ bermudagrass hybrid) is a classic example of improving $\mathrm{C}_{4}$ grass digestibility via plant breeding and selection, as reported by Lowrey et al. (1968), Chapman et al. (1972) and Utley et al. (1974). A switchgrass (Panicum virgatum) strain (Trailblazer) selected for increased in vitro dry matter digestibility (IVDMD) (Vogel et al., 1984; Anderson et al., 1988) produced significantly higher grazing gains than did Pathfinder or a low-IVDMD strain of switchgrass. Fisher et al. (1985) reported that traditional methods of sampling switchgrass did not account for selective grazing of available forage and underestimated diet digestibility. They hypothesized that yearlings grazing Trailblazer switchgrass exhibited increased performance because of their ability to select differentially a higher-quality forage than was available to yearlings grazing other strains. Objectives of 
this study were to determine whether differences exist in selectivity and digestibility among Trailblazer, Pathfinder and low-IVDMD strains of switchgrass in grazing and digestion trials.

\section{Materials and Mothods}

Trial 1: Animal Selectivity. Trial 1 was conducted to test the hypothesis that yearling cattle were selecting higher-quality diets when compared with Pathfinder or low-IVDMD strains and higher than hand-clipped forage samples. Six esophageally fistulated crossbred steers (avg wt $900 \mathrm{~kg}$ ) were used in a $3 \times 3$ replicated latin square design to collect esophageal extrusa samples. Blocking variables were steer, pasture and sampling date. The design used for collection of top and whole plant clipped samples was a split plot in time with switchgrass strains as the main plot and periods (times) as the subplot (Gill and Hafs, 1971). Trailblazer, Pathfinder and low-IVDMD switchgrass pastures of .4 ha each were established in a randomized complete block design with four replicates per strain. Six of the 12 available pastures were used for extrusa sample collection, providing two replications of each respective strain. The remaining six pastures were used as holding areas. When not being used for test pasture extrusa collection, fistulated steers grazed in holding pastures containing the next switchgrass strain they were to test.

To simulate grazing conditions described by Anderson et al. (1988), three yearling steers were placed on test pastures between sampling periods to maintain vegetative switchgrass growth between 25 and $50 \mathrm{~cm}$ in height. Extrusa samples were collected at three different vegetative periods during the summer of 1984: Period 1, June 11, 13, 14; Period 2, July 9 to 11; and Period 3, July 30, 31, August 1 . Ten days before each sampling period, fistulated steers were placed in test pastures and yearling steers were moved to respective holding pastures. Fistulated steers were rotated among the three switchgrass strains to assure that each steer grazed each respective strain within a replication. All steers had free access to a trace mineral-vitamin $\operatorname{mix}(\mathrm{Fe}, \mathrm{Zn}, \mathrm{Cu}$, $\mathrm{Mg}, \mathrm{Mn}, \mathrm{Co}, \mathrm{S}, \mathrm{K}$ and Vitamin A), iodized salt blocks and water.

Esophageal extrusa collections were taken at 0700 each collection day for $30 \mathrm{~min}$ or until bags were full. Fistulated steers were not fasted before collection. During collections, water access was denied and trace mineralvitamin mix and salt blocks were removed. Extrusa samples were heated in a microwave for $3 \mathrm{~min}$ to deactivate plant enzymes (Burns, 1981), and frozen within $3 \mathrm{~h}$ after collection. Hand-clipped top and whole plant forage samples were collected by methods described by Anderson et al. (1988) at times coinciding with sampling periods. Portions of each extrusa sample were lyophilized. Hand-clipped forage samples were dried in a forced-air oven at $50^{\circ} \mathrm{C}$. All samples were ground to pass a 1 $\mathrm{mm}$ screen in preparation for laboratory analysis. Extrusa samples from individual steers within a collection period were subsampled and composited.

Extrusa and hand-clipped forage samples were analyzed for in vitro organic matter disappearance (IVOMD) by the Tilley and Terry (1963) technique, NDF and ADF as described by Goering and Van Soest (1970), CP according to AOAC (1975), lignin as described by Van Soest and Wine (1968), ash by heating to $600^{\circ} \mathrm{C}$ for $12 \mathrm{~h}$ and $\mathrm{DM}$ by drying a $100^{\circ} \mathrm{C}$ to a constant weight. The IVOMD two-stage technique was modified to include $1 \mathrm{~g}$ urea per liter of buffer and to include buffer and rumen liquor in a $2: 1$ ratio. Rumen inoculum was obtained from two crossbred steers, one on a constant alfalfa (Medicago sativa) diet and the other on a constant corn (Zea mays) cob diet. Each steer donated $50 \%$ of the inoculum. Fermentation of samples lasted $48 \mathrm{~h}$ and was followed by an acid-pepsin digestion of $24 \mathrm{~h}$.

Esophageal data were analyzed as a $3 \times 3$ latin square according to methods described by Steel and Torrie (1980). The General Linear Models (GLM) procedure of SAS (1984) was used with individual pastures considered as the experimental unit. Means for extrusa, top and whole plant hand-clipped samples from the three collection periods were determined to make comparisons between esophageal and clipped samples. The three period strain means were analyzed as a randomized complete block, according to methods outlined by Steel and Torrie (1980), as follows: 1) within respective sample type, 2) by the difference between extrusa minus top samples and 3 ) by the difference between extrusa minus whole plant samples.

Trial 2: Lamb Intake and Digestion. To further evaluate switchgrass strains, a lamb 
digestion trial was conducted with the specific objective of comparing Trailblazer and Pathfinder switchgrass hay. Forage from each cultivar was harvested as hay at early head emergence (from holding pastures in Trial 1) and ground through a tub grinder with a 2.54$\mathrm{cm}$ screen in preparation for feeding. Twelve mature mixed-breed wethers averaging $54 \mathrm{~kg}$ were assigned randomly (six per treatment) using a completely random design. Two wethers from the Trailblazer group subsequently were removed because of illness unrelated to the study. Wethers were fed a protein supplement (containing 16.3, 57.1, 25.8 and $.7 \%$ urea, com cobs, com and monosodium phosphate, respectively, on a DM basis), at $8 \%$ of DMI along with $3 \mathrm{~g}$ tracemineral vitamin mix head $^{-1} \cdot \mathbf{d}^{-1}$ (Trial 1). Urea was included in the supplement to aid in supplying adequate rumen ammonia. Energy was adequate from hay sources for maintenance of mature wethers (Ward and Ward, 1987). Wethers were housed in individual metabolism crates located in an environmentally regulated room maintained at $23^{\circ} \mathrm{C}$ with constant illumination. All wethers previously had been fed a diet of ground corn cobs.

Wethers in the digestion trial began a 10-d ad libitum intake phase followed by an 11-d restricted (90\%) intake phase (Heaney, 1969). Forages and supplement were sampled during each feeding period; samples then were mixed and sub-sampled. Wethers were fitted with canvas fecal collection bags and total fecal output was collected the last $7 \mathrm{~d}$ of the restricted intake phase. Wethers were fed at 1600 each day, with feces collected prior to feeding. Feces were weighed, sub-sampled, dried in a forced-air oven at $65^{\circ} \mathrm{C}$ and fecal, forage and supplement samples were ground to pass a 1-mm screen in preparation for laboratory analysis.

All hay, supplement and fecal samples were analyzed for DM, NDF, ADF and CP utilizing methods described under Trial 1. Apparent digestibility calculations of dry matter (DMD), NDF (NDFD), ADF (ADFD) and CP (CPD) were made. Results were analyzed as a completely randomized design according to methods outlined by Steel and Torrie (1980). The GLM procedure of SAS (1984) was used with individual wethers considered as experimental units.

\section{Results and Discussion}

Trial 1: Animal Selectivity. Trailblazer extrusa was higher $(P<.1)$ in IVOMD than Pathfinder or low-IVDMD extrusa (Table 1). Trailblazer extrusa was lower $(P<.1)$ in NDF and ADF than Pathfinder extrusa. No difference $(P>.1)$ among strains existed in extrusa samples for $\mathrm{CP}$, lignin and ash.

Extrusa samples from all three strains (Table 1) tended to be higher in IVOMD, CP and ash and lower in NDF and lignin than top hand-clipped samples (Table 2). This agrees with work of other researchers (Kiesling et al., 1969; Coleman and Barth, 1973). Trailblazer top hand-clipped samples tended to be higher in IVOMD than Pathfinder $(P<.30)$ or lowIVDMD $(P<.17)$ top samples, whereas no differences existed among strains for $\mathrm{CP}$, NDF, ADF, lignin or ash. These results agree with clip-sample data of Anderson et al. (1988), who reported significant differences among strains in the same pastures for top and whole plant IVOMD. In that study, statistical

TABLE 1. LABORATORY ANALYSES (\%) OF ESOPHAGEAL SAMPLES FROM SWITCHGRASS STRAINS"

\begin{tabular}{lllllll}
\hline Strain & IVOMD $^{\text {bc }}$ & CP & NDF & ADF & Lignin & Ash \\
\hline Trailblazer & 78.0 & 13.6 & 75.4 & 43.9 & 4.7 & 10.3 \\
Pathfinder & 75.9 & 14.1 & 77.7 & 46.6 & 4.8 & 12.9 \\
Low-IVDMD & 75.5 & 13.1 & 75.4 & 45.0 & 4.9 & 11.3 \\
SE & 1.24 & .60 & 1.57 & 1.62 & .26 & 1.37 \\
\hline
\end{tabular}

Organic matter basis.

'In vitro organic matter disappearance.

Trailblazer IVOMD was greater $(P<.1)$ than that of Pathfinder and low-IVDMD.

Trailblazer NDF and ADF were lower $(P<.1)$ than that of Pathfinder.

'SE, $n=6$. 
GRAZING SELECTIVITY ON SWITCHGRASS

TABLE 2. LABORATORY ANALYSES (\%) OF TOP HAND-CLIPPED SAMPLES FROM SWITCHGRASS STRAINS"

\begin{tabular}{lccccccc}
\hline \hline Strain & IVOMD & CP & NDF & ADF & Lignin & Ash & \\
\hline Trailblazer & 69.9 & 12.6 & 83.8 & 43.3 & 5.6 & 7.2 \\
Pathfinder & 67.3 & 12.7 & 82.7 & 42.5 & 5.5 & 7.2 \\
Low-IVDMD & 66.0 & 12.7 & 82.3 & 42.8 & 5.2 & 7.2 & .03 \\
SEd $^{d}$ & .92 & .10 & .35 & .48 & .17 & .03 \\
\hline
\end{tabular}

Organic matter basis.

bIn vitro organic matter disappearance.

Trailblazer IVOMD was greater $(P<.30)$ than that of Pathfinder and low-IVDMD $(P<.17)$.

$\mathbf{d S E}, \mathbf{n}=2$.

precision was greater because each switchgrass strain was replicated four times; in this study each strain was replicated twice because of the limited number of esophageally fistulated steers available. In the present study, IVOMD and $\mathrm{CP}$ of top hand-clipped samples decreased, whereas NDF, ADF, lignin and ash increased during plant maturation.

Extrusa samples from each strain (Table 1) tended to be higher in IVOMD, CP and ash and lower in NDF, ADF and lignin than whole plant hand-clipped samples (Table 3), indicating that the animals had an ability to differentially select higher-quality forage in comparison to the whole plant. This agrees with Weir et al. (1959), Barth and Kazzal (1971) and Fisher et al. (1985). Trailblazer and Pathfinder whole plant hand-clipped samples tended to be higher $(P<.22)$ in IVOMD than low-IVDMD samples. As with top handclipped samples, differences in whole plants among strains for CP, NDF, ADF, lignin or ash were small. Maturation trends were consistent with extrusa and hand-clipped samples with whole plant IVOMD and CP decreasing, whereas NDF, ADF, and lignin increased. Laboratory analysis by vegetative period of extrusa, top and whole plant hand-clipped samples for IVOMD, CP, NDF, ADF, lignin and ash has been reported by Ward (1985).

In vitro organic matter disappearance differences between strains of switchgrass for animal selection (extrusa minus top handclipped samples; Table 4) were not significant, suggesting that fistulated steers did not selectively differentiate between varieties of switchgrass. This indicates that the higher IVOMD of Trailblazer esophageal extrusa was due to higher IVOMD of the upper portion of the plant.

The difference between extrusa and whole plant hand-clipped samples for IVOMD and ADF was higher $(P<.05$ and $P<.01$, respectively) for Trailblazer than for Pathfinder switchgrass (Table 5). However, differences were similar in magnitude to those reported in Table 1, indicating that steers did not select differently based on switchgrass strain. Strains

TABLE 3. LABORATORY ANALYSES (\%) OF WHOLE PLANT HAND-CLIPPED SAMPLES FROM SWITCHGRASS STRAINS"

\begin{tabular}{lllllll}
\hline \hline Strain & IVOMD $^{\mathrm{bc}}$ & CP & NDF & ADF & Lignin & Ash \\
\hline Trailblazer & 65.0 & 10.3 & 83.7 & 47.5 & 6.8 & 8.4 \\
Pathfinder & 65.7 & 10.7 & 83.9 & 47.9 & 7.2 & 9.0 \\
Low-IVDMD & 62.8 & 9.5 & 84.5 & 49.3 & 7.5 & 8.7 \\
SE $^{\mathrm{d}}$ & .58 & .35 & .06 & .55 & .17 & .16 \\
\hline
\end{tabular}

Organic manter basis.

'In vitro organic matter disappearance.

Trailblazer and Pathfinder IVOMD was greater $(P<.22)$ than that of low-IVDMD.

${ }^{d} \mathrm{SE}, \mathrm{n}=\mathbf{2}$. 
TABLE 4. LABORATORY ANALYSES (\%) FOR MEAN DIFFERENCE OF EXTRUSA MINUS TOP HAND-CLIPPED SAMPLES FROM SWITCHGRASS STRAINS"

\begin{tabular}{|c|c|c|c|c|c|c|}
\hline Strain & IVOMD $^{6}$ & $\mathrm{CP}$ & NDF & ADF & Lignin & Ash \\
\hline $\begin{array}{l}\text { Trailblazer } \\
\text { Pathfinder } \\
\text { Low-IVDMD } \\
\text { SE }^{\text {e }}\end{array}$ & $\begin{array}{l}8.1 \\
8.6 \\
9.5 \\
1.97\end{array}$ & $\begin{array}{c}.9 \\
1.4 \\
.4 \\
.24\end{array}$ & $\begin{array}{l}-8.4 \\
-4.9 \\
-6.9 \\
1.41\end{array}$ & $\begin{array}{l}.6 \\
4.1 \\
2.1 \\
1.31\end{array}$ & $\begin{array}{l}-.9 \\
-.7 \\
-.3 \\
.20\end{array}$ & $\begin{array}{c}3.1 \\
5.7 \\
4.1 \\
.20\end{array}$ \\
\hline
\end{tabular}

Organic matter basis.

In vitro organic matter disappearance.

'SE, $\mathbf{n}=2$.

were similar $(P>.1)$ in the difference between top and whole plant samples for all laboratory analyses.

Quantitative comparisons made between oven-dried forage samples and lyophilized extrusa samples may have been biased, but Burns (1981) reported that relative rankings between oven-dried and lyophilized forage samples were similar. Data from the present study may be used to explain performance differences observed by Anderson et al. (1988). After a grazing animal has fulfilled body maintenance requirements, any additional intake of energy (e.g., from a more digestible forage) is used for gain. Fistulated steers consumed diets higher in IVOMD (Table 1) when grazing Trailblazer switchgrass. Assuming grazing yearlings and fistulated cattle select similar diets, yearling cattle grazing Trailblazer (Anderson et al., 1988) had more total dietary energy available for gain; this can account for performance differences observed between switchgrass strains. Because animals commonly graze upper leafy portions of a vegetative plant prior to the lower portions
(Johnston-Wallace and Kennedy, 1944; Alder and Minson, 1963) this also may have contributed to performance differences because Trailblazer extrusa (Table 1) was more digestible than Pathfinder or low-IVDMD extrusa. Differences observed for IVOMD between strains was limited for whole plant samples (Table 3), but previous data (Anderson et al., 1988) have shown higher whole-plant IVDMD for Trailblazer.

Trailblazer was selected on the basis of whole-plant IVDMD. Data from the present study suggests that plant breeders should consider developing strains that are more digestible in their upper leafy portions; this is in agreement with data reported by Burns et al. (1984) and Fisher et al. (1985). Whether this can be done more effectively by direct selection for upper plant digestibility, leaf digestibility, or whole plant digestibility remains to be determined.

Trial 2: Lamb Digestion Trial. Differences between Trailblazer or Pathfinder switchgrass for DMI, DMD, NDFD, ADFD or CPD by wethers were small $(P>.05$; Table 6). Prigge

TABLE 5. LABORATORY ANALYSES (\%) FOR MEAN DIFFERENCE OF EXTRUSA MINUS WHOLE PLANT HAND-CLIPPED SAMPLES FROM SWITCHGRASS STRAINS"

\begin{tabular}{|c|c|c|c|c|c|c|}
\hline Strain & IVOMD $^{\mathrm{D}}$ & $\mathrm{CP}$ & NDF & $A D F^{4}$ & Lignin & Ash \\
\hline $\begin{array}{l}\text { Trailblazer } \\
\text { Pathfinder } \\
\text { Low-IVDMD } \\
\text { SE־ }\end{array}$ & $\begin{array}{l}13 \\
10.2 \\
12.7 \\
.27\end{array}$ & $\begin{array}{l}3.3 \\
3.4 \\
3 . .6 \\
.21\end{array}$ & $\begin{array}{r}-8.3 \\
-6.2 \\
-9.1 \\
.97\end{array}$ & $\begin{array}{r}-3.5 \\
-1.2 \\
-4.3 \\
.14\end{array}$ & $\begin{array}{c}-2.2 \\
-2.4 \\
-2.6 \\
.28\end{array}$ & $\begin{array}{l}2 \\
3.9 \\
2.6 \\
.28\end{array}$ \\
\hline
\end{tabular}

Organic matter basis.

'In vitro organic matter disappearance.

Trailblazer IVOMD difference was greater $(P<.05)$ than that of Pathfinder.

Trailblazer ADF difference was greater $(P<.01)$ than that of Pathfinder.

'SE, $\mathrm{n}=\mathbf{2}$. 
GRAZING SELECTIVITY ON SWITCHGRASS

TABLE 6. INTAKE (ORAMS/DAY) AND APPARENT DIGESTIBILJTY (\%) FOR SWITCHGRASS LAMB TRIAL:

\begin{tabular}{lllllllllll}
\hline \hline Treatment & DMI $^{b}$ & SE & DMD & SE & NDFD & SE & ADFD & SE & CPD $^{*}$ & SE $^{*}$ \\
\hline Trailblazer & 1,180 & 46 & 56.1 & 3.2 & 58.9 & 3.3 & 52.9 & 3.7 & 72.5 & 1.7 \\
Pathfinder & 1,156 & 32.5 & 55.2 & 2.2 & 55.7 & 2.3 & 52.9 & 2.6 & 72.1 & 1.2 \\
\hline
\end{tabular}

'Dry matter basis.

Dry matrer intake ( $90 \%$ ad libitum).

'Dry matter digestibility.

Neutral detergent fiber digestibility.

'Acid detergent fiber digestibility.

'Crude protein digestibility.

sSE, Trailblazer, $n=4 ;$ Pathfinder, $n=6$.

TABLE 7. CHEMICAL COMPOSITION (\%) OF HAYS AND SUPPLEMENT USED IN SWITCHGRASS LAMB DIGESTION TRIAL"

\begin{tabular}{lllll}
\hline \hline Treatment & IVDMD $^{6}$ & CP & NDF & ADF \\
\hline Trailblazer & 58.9 & 13.3 & 77.5 & 50.2 \\
Pathfinder & 55.1 & 8.7 & 77.4 & 50.8 \\
Supplement & 59.8 & 71.3 & 68.4 & 22.0 \\
\hline
\end{tabular}

Dry matter basis.

'In vitro dry matter disappearance.

et al. (1984) reported similar DMI and digestibility values, except for lower protein digestibility, whereas Vona et al. (1984) reported lower digestibility values when feeding mature switchgrass hay to wethers. Vogel et al. (1984) also reported no observable differences for DMI and apparent digestibility when using sheep to evaluate the same respective switchgrass strains. Chemical composition of switchgrass hay is shown in Table 7. Laboratory analyses from Trial 1 showed Trailblazer to be more digestible than Pathfinder switchgrass, which provided an opportunity for increased DMI (Montgomery and Baumgardt, 1965). Monson et al. (1977) and Howarth and Goplen (1983) reported that morphological differences between forages can cause high quality to be lost upon grinding. Sheep in this study could not detect strain differences when fed switchgrass as chopped hay; this is in agreement with Vogel et al. (1984).

Esophageally fistulated steers selected diets higher in IVOMD and lower in NDF when grazing Trailblazer compared with Pathfinder or low-IVDMD switchgrass. However, in a lamb digestion trial, there were no differences in DMI or digestibility between Trailblazer and Pathfinder switchgrass hay.

\section{Literature Clted}

Alder, F. E. and D. J. Minson. 1963. The herbage intake of cattle grazing lucerne and cocksfoot pastures. J. Agric. Sci. 60:359.

Anderson, B. E., J. K. Ward, K. P. Vogel, M. G. Ward, H. J. Gorz and F. A. Haskins. 1988. Forage quality and performance of yearlings grazing switchgrass strains differing in digestibility. J. Anim. Sci. 66:2239.

AOAC. 1975. Official methods of Analysis (12th Ed.). Association of Official Analytical Chemists, Washington, DC.

Barth, K. M. and N. T. Kazzal. 1971. Separation of true selective grazing by cattle from effects of esophageal fistula. J. Anim. Sci. 33:1124.

Burns, J. C. 1981. Drying of fresh herbage samples for laboratory estimates of quality. In: J.L. Wheeler and R. D. Mochrie (Ed.) Forage Evaluation: Concepts and Techniques. CSIRO, East Melbourne, Victoria, Aust.

Burns, J. C., R. D. Mochric and D. H. Timothy. 1984. Steer performance from two pennisetum species, switchgrass and a fescue-coastal bermudagrass system. Agron. J. 76:795.

Burton, G. W. 1974. Improving forage quality by breeding. Proc. 12th Int. Grassl. Congress. Sect. 2:21. (Moscow, USSR).

Burton, G. W. and W. G. Monson. 1981. Nutrient composition of forage crops. Effects of genetic factors and agronomic practices. USDA-ARS Agriculnural 
Reviews and Manuals. ARM-S-21.

Chapman, H. D., W. H. Marchant, P. R. Utley, R. E. Hellwig and W. G. Monson. 1972. Performance of steers on Pensacola bahiagrass, Coastal bermudagrass and Coastcross-1 bermudagrass pastures and pellets. J. Anim. Sci. 34:373;

Coleman, S. W. and K. M. Barth. 1973. Quality of diets selected by grazing animals and its relation to quality of available forage and species composition of pastures. J. Anim. Sci. 36:754.

Fisher, D. S., K. R. Pond, J. C. Burns, R. D. Mochrie and D. H. Timothy. 1985. Selection, mastication and digestive tract response of cattle to plant canopy and composition. Proc. 15th Int. Grassl. Cong. 3:1117. Kyoto, Japan.

Gill, J. L. and H. D. Hafs. 1971. Analysis of repeated measurements of animals. J. Anim. Sci. 33:331.

Goering, H. K. and P. J. Van Soest. 1970. Forage Fiber analysis (apparatus, reagents, procedures, and some applications). Agric. Handbook 379. ARS, USDA, Washington, DC.

Heaney, D. P. 1969. Voluntary intake as a component of an index to forage quality. Proc. of the Natl. Conf. on Forage Qual. Eval. and Util. Paper C. Lincoln, Nebraska.

Howarth, R. E. and B. P. Goplen. 1983. Improvement of forage quality through production management and plant breeding. Can. J. Plant. Sci. 63:895.

Johnston-Wallace, D. B. and K. Kennedy. 1944. Grazing management practices and their relationship to the behavior and grazing habits of cattle. J. Agric. Sci. 34: 190.

Keisling, H. E., A. B. Nelson and G. H. Herble. 1969 Chemical composition of tobassa grass collected by hand-plucking and esophageal-fistulated steers. I Range Mange. 22:155.

Lowrey, R. S., G. W. Burton, J. C. Johnson, Jr., W. H. Marchant and W. C. McCormick. 1968. In vivo studies with coastcross-I and other bermudas. Georgia Agric. Exp. Sta. Res. Bull. 55, Athens.

Monson, W. G., G. W. Burton and W. W. Hanna. 1977. Evaluation of quality factors in warm-season forages. Proc. 13th Int. Grassl. Cong. 1:403 Leipzig, GDR

Montgomery, M. S. and B. R. Baumgardt. 1965. Regulation of food intake in ruminants. 2. Pelleted rations varying in energy concentrations. J. Dairy Sci. 48:569.

Moore, J. E. and G. O. Mott. 1973. Structural inhibitors of quality in tropical grasses. In: A. G. Matches (Ed.)
Anti-Quality Components of Forages. Crop Sci. Soc. of Am. Inc., Special Publ. No. 4:53. Madison, WI.

Prigge, E. C., M. J. Baker and G. A. Varga. 1984. Comparative digestion, rumen fermentation and kinetics of forage diets by steers and wethers. J. Anim. Sci. 59:237.

SAS. 1984. SAS User's Guide: Statistics. SAS Inst., Inc., Cary, NC.

Steel, R.G.D. and J. H. Torrie. 1980. Principles and Procedures of Statistics (2nd Ed.). McGraw-Hill Book Co., New York.

Tilley, J.M.S. and R. A. Terry. 1963. A two-stage technique for the in vitro digestion of forage crops. J. Br. Grassl. Soc. 18:104.

Utley, P. R., H. D. Chapman, W. G. Monson, W. H. Marchant and W. C. McCormick. 1974. Coastcross-1 bermudagrass, Coastal bermudagrass and Pensacola bahiagrass as summer pasture for steers. J. Anim. Sci. 38:490.

Van Soest, P. J. and R. H. Wine. 1968. Determination of lignin and cellulose in acid detergent fiber with permanganate. J. Assoc. Off. Anal. Chem. 51:780.

Vogel, K. P., R. Britton, H. J. Gorz and F. A. Haskins. 1984. In vitro and in vivo analyses of hays of switchgrass strains selected for high and low in vitro dry matter digestibility. Crop Sci. 24:877.

Vona, L. C., G. A. Jung, R. L. Reid and W. C. Sharp. 1984. Nutritive value of warm-season grass hays for beef cattle and sheep; digestibility, intake and mineral utilization. J. Anim. Sci. 59:1582.

Ward, M. G. 1985. Grazed switchgrass and ammoniated switchgrass or big bluestem hay for beef cattle. M. S. Thesis. Univ. of Nebraska, Lincoln.

Ward, M. G. and J. K. Ward. 1987. Ammoniation of warmseason grass hay for gestating beef cows. J. Anim. Sci. 65:359.

Weir, W. C., J. H. Meyer and G. F. Lofgreen. 1959. Symposium on forage evaluation: VI. The uses of the esophageal fistula, lignin and chromagen techniques for studying selective grazing and digestibility of range and pasture by sheep and cattle. Agron. J. 51:235.

Wilson, J. R., R. H. Brown and W. R. Windham. 1983. Influence of leaf anatomy of the dry mater digestibility of $\mathrm{C}_{3}, \mathrm{C}_{4}$ and $\mathrm{C}_{3} / \mathrm{C}_{4}$ intermediate types of panicum species. Crop Sci. 23:141. 